\title{
AKHLAQ DALAM PERSPEKTIF SUFISTIK
}

\begin{abstract}
Achmad $^{*}$
Abstrak

Al Qur-an suci menyabdakan, terjemahnya,"Kecuali (adalah bagi) orang-orang yang menghadapkan diri kepada Allah dengan hati yang bersih....(Q.S.26:89). Kebalikannya,"...yang di dalam hatinya ada penyakit," (Q.S.2:10). Orang ini diberi mata,dapat melihat bintang, bulan, matahari,bahkan dapat melihat atom, tetapi tidak dapat melihat dirinya sendiri. "Mata mereka tidak buta tetapi yang buta adalah hati yang ada di dalam dada (Q.S.22:46). Islam saat membicarakan akhlaq tidak hanya berdimensi jasadi, perbuatan dhahir, juga ada dimensi batini yang bersumber dari hati. Di hati utamanya tempat iman, tashdiqun bil qalbi, pembenaran di hati, sehingga akhlaq tidak dapat dipisahkan dengan iman.Urgensinya akhlaq berada pada tataran kedekatan dan kecintaan Allah ta'ala. Secara duniawy mendatangkan manfaat bagi diri, siapa, apa, dan menempati maqam taqwa. Secara ukhrawy menikmati kelezatan surgawy sebagai kebahagian hidup yang sempurna.
\end{abstract}

Kata kunci : akhlaq, dhahir, batin, taqwa

Akhlaq adalah ajaran Islam, orang Jawa menyebutnya tata krama, budhi pekerti atau budhi luhur, keadaan budhi atau batin yang mewujud dalam tingkah laku. Akhlaq yang asalnya dari lafal khuluq adalah bahasa Arab, suatu kebiasaan yang didorong oleh kehendak atau iradah, al'aadatul iraadah, demikian Ahmad Amin dalam kitabnya Akhlaq (Rahmat Jatnika, 1975). Iradah terbagi menjadi dua macam, yaitu kehendak yang baik dan buruk (Asy Syams 9), dan memang akhlaq itu membahas tentang baik, buruk, terpuji, hina, salah, dan betul.

Akhlaq adalah institusi yang bersemayam di hati, wujudnya tindakan suka rela, perbuatan betul atau salah. Dalam fitrahnya institusi ini siap menerima pengaruh pembinaan yang baik atau pembinaan yang buruk. Bila institusi ini senantiasa dibina dengan keutamaan, cinta kebaikan, benci keburukan, maka menjadi trade-marknya perbuatan baik muncul dengan mudah. Misal saja, lemah lembut, sabar, dermawan, berani, adil, sebagai penyempurna diri (Abubakar Jabir al Jazairi, 2005), amar ma'ruf dan nahi munkar, menyuruh yang baik dan berani mencegah yang munkar (Al Qur-an).

\footnotetext{
${ }^{*}$ Dosen UPM Soshum ITS

jsh Jurnal Sosial Humaniora, Vol 4 No.1, Juni 2011 
Akhlaq mempunyai keterhubungan dengan iman dan ibadah, artinya akhlaq dilandasi iman dan ibadah. Iman sebagai tatanan batin mewujud ibadah sebagai tata dhahir, tetapi ibadah tidak hanya tata dhahir saja karena ibadah sendiri juga ada tata batinnya, tentu tata batin dalam konteks ibadah, hal ini untuk membedakan iman sebagai tata batin dan di dalam ibadah ada tata batin. Ibadah yang dilaksanakan secara dhahir dan batin menghasilkan akhlaq, dan insya Allah ta'ala akhlaq yang karimah atau luhur. Iman dan ibadah yang benar tidak menghasilkan akhlaq yang tercela atau hina, sedang lemahnya iman dan tidak benarnya ibadah membuahkan akhlaq yang buruk.

Penilaian terhadap perilaku seseorang itu baik atau buruk, salah atau betul, tentu bukan salah atau benar karena konteksnya bukan theologi, terpuji atau hina cenderung ditentukan berdasar perasaan atau pikiran, kepentingan ataupun tujuan tertentu dari seseorang.

Banyak ahli pendidikan berpendapat tentang urgensinya pendidikan karakter bangsa yang pasti sejak bangsa ini berdiri merdeka seharusnya pendidikan karakter dibudayakan melalui pendidikan formal. Sebagaimana Presiden Republik Indonesia yang pertama yaitu Bung Karno menegaskan pentingnya pembangunan karakter bangsa. Namun apa yang telah Presiden tegaskan saat itu kurang dibarengi dengan upaya konkrit dari pengambil kebijakan di negeri ini, tentu khususnya dalam pembangunan moral bangsa.

\section{Pendidikan Agama pada masa Orde Lama dan Orde Baru}

Pada masa orde lama, hal yang mengedepan bagi bangsa ini adalah percaturan politik kekuasaan oleh partai-partai politik, dan puncaknya terjadi makar atau pemberontakan yang dilakukan oleh Partai Komunis Indonesia yang disingkat PKI terhadap pemerintah yang sah dengan cara membantai beberapa Jenderal Angkatan Darat. Pemberontakan itu akhirnya dapat ditumpas dan sekaligus dibubarkan partai tersebut.

Sekitar tahun 1960-an pendidikan agama diajarkan mulai dari Sekolah Rakyat Negeri yang sekarang menjadi Sekolah Dasar Negeri, pendidikan agama baru diajarkan pada kelas VI dan tentunya baru beberapa Sekolah Rakyat Negeri 
yang terdapat di kota Kabupaten. Artinya Sekolah Rakyat Negeri yang ada di pelosok desa jauh dari kota Kabupaten belum tersentuh pendidikan agama.

Pada masa awal orde baru jumlah guru agama bertambah, dan meratanya pendidikan agama di tingkat Sekolah Dasar Negeri, Sekolah Menengah Pertama Negeri, maupun Sekolah Menengah Atas Negeri pada masa pertengahan orde baru, sekitar tahun 1980-an. Namun disisi lain kemungkaran yang diseponsori oleh pemerintah tidak ada yang dapat membendung, yakni membudayanya judi yang resmi sepesrti lotto, nalo, porkas, sumbangan dana sosial berhadiah yang disingkat SDSB. Judi yang tidak resmi tetapi legal adalah judi buntutan.

Berbagai macam judi di atas telak merusak akhlaq mayoritas masyarakat kalangan bawah, karena judi sudah menjadi lahan pekerjaan hampir setiap orang.

\section{Sumber Nilai dan Norma Kehidupan}

Islam adalah sistem kehidupan yang berisi petunjuk untuk menjalani hidup dan kehidupan, diaturnya hubungan manusia dengan Rabbnya yaitu Allah SWT. dan hubungan manusia dengan alam semesta, yang pasti di dalamnya ada hubungan manusia dengan manusia.

Sumber utama ajaran Islam adalah Al Qur'an, baru kemudian Al Hadits atau As Sunnah. Dari dua sumber tersebut ajaran akhlaq diambil dan dikembangkan yang pada perkembangannya menjadi ilmu akhlaq. Seseorang dalam melaksanakan suatu perbuatan ataupun tidak melaksanakannya tentu didasari dan didorong oleh nilainilai yang diyakini dan dianut. Seperangkat keyakinan tentang baik, buruk, betul, salah, terpuji, hina, patut, tidak patut yang mendorongnya untuk melakukan atau tidak melakukan. Demikian norma-norma kehidupan juga berasal dari Al Qur-an dan Al Hadits, suatu ukuran standar untuk menentukan apakah suatu perbuatan yang dilakukan manusia, secara individual ataupun kolektif itu baik atau buruk, bahkan berdosa ataukah berpahala.

\section{Sifat Norma Akhlaq}

Akhlaq yang mulya merupakan inti dari tujuan setiap Nabi dan Rasul diutus, untuk mengubah rusaknya akhlaq kaum atau ummat di mana Nabi dan Rasul itu 
dibangkit. Demikian juga ummat dibelakang Nabi atau Rasul itu untuk meneladani dalam kehidupannya ketinggian dan keluhuran akhlaq Nabinya.

Teladan terbaik ummat adalah Nabi Muhammad SAW., dan ini difirmankan Allah swt. di dalam Al Qur-an, yang terjemahnya,"Sungguh bagi kamu pada diri Rasul itu teladan yang baik." Dan Rasulullah Muhammad SAW. bersabda yang terjemahnya,"Sesungguhnya aku diutus untuk menyempurnakan akhlaq yang mulya." Dari sini ditegaskan bahwa norma akhlaq itu memiliki sifat sakral, absolut, imperatif, akurat, dan universal.

Sifat sakral pada norma akhlaq Islam, karena akhlaq landasannya Al Qur-an sebagai wahyu dari Allah ta'ala, yang suci dan disucikan. Isi kandungannya suci, mengamalkan isinya merupakan bentuk ketaatan kepada Allah SWT. dan bernilai ibadah. Pengamalan perintah Allah ta'ala dalam tataran akhlaq yang baik apa yang diprintahkan, didorongkan, dipuji, dan diharapkan oleh Islam untuk dilakukan berdampak pahala dan kemulyaan, sebaliknya menolak dan melecehkannya berdampak dosa dan kehinaan. Model perilaku yang baik dalam Islam sering disebut al akhlaq al karimah atau al akhlaq al mahmudah, model perilaku yang buruk disebut al akhlaq al sayyi'ah atau al akhlaq al madzmumah.

Norma akhlaq Islam adalah absolut, dalam pengertian memiliki kemutlakan dalam penetapan standar baik, buruk, betul, salah, terpuji, hina, dan baku tidak berubah dalam masyarakat yang berbeda budaya maupun berbeda waktu atau zaman. Imperatif yang artinya mengikat, norma akhlaq Islam mengikat orang Islam, bahwa muslim wajib berakhlaq sebagaimana termaktub di dalam dua sumber pedoman hidupnya yaitu Al Qur-an dan As Sunnah. Akurat, artinya sangat tepat norma akhlaq untuk mengendalikan perilaku manusia sehingga kehidupan menjadi rukun, damai, tenteram. Norma akhlaq adalah universal, norma itu berlaku kapan dan di mana saja, tidak hanya manfaatnya dirasa di dunia ini saja, tetapi juga berdampak di akhirat.

\section{Hal-hal yang Berhubungan dengan Akhlaq}

Di atas telah disebut bahwa akhlaq dilandasi iman dan direalisasikan dalam ibadah. Ibadah menghasilkan akhlaq, dan akhlaq mempunyai hubungan dengan muraqabah, muhasabah, maupun takut. Muraqabah, adalah kondisi batin Muslim 
yang merasa dan yakin bahwa dhahir dan batinnya diawasi Allah ta'ala. Bagi Allah ta'ala tidak ada yang luput dari pengawasanNya atas setiap makhlukNya. Seorang yang muraqabatullah, akan merasakan betapa keagungan dan kesempurnaan Allah ta'ala, sehingga merasa tenteram dalam taat kepadaNya.

Terjemah Al Qur-an sebagai dalil muraqabah : Surah Yunus ayat 22,'Kamu tidak berada dalam suatu kadaan dan tidak membaca suatu ayat dari Al Qur-an dan kalian tidak mengerjakan suatu pekerjaan, melainkan Kami menjadi saksi atasmu pada waktu kalian melakukannya." Surah Al Baqarah ayat 235,"Dan ketahuilah bahwasanya Allah mengetahui apa yang ada dalam hatimu maka takutlah kepadaNya." Surah Luqman ayat 22,"Dan barangsiapa yang menyerahkan dirinya kepada Allah, sedang dia orang yang berbuat kebaikan, maka sesungguhnya ia telah berpegang pada buhul tali yang kokoh."

Terjemah sabda Nabi Muhammad SAW.,'Hendaknya engkau beribadah kepada Allah seolah-olah engkau melihatNya. Jika engkau tidak bisa melihatNya, maka sesungguhnya Dia melihatmu." Muqarrabin, adalah orang yang telah mencapai derajat dekat dengan Allah ta'ala, dan mereka itu telah memiliki sifat muraqabah. Misal dan ungkapannya tentang muraqabah, adalah : Dinyatakan kepada Al Junaid,"Bagaimana kiat menahan pandangan ?" Al Junaid menjawab,"Yaitu pengetahuanmu, bahwa pandangan Dzat yang melihatmu itu lebih dahulu dan lebih cepat daripada penglihatanmu kepada sesuatu yang engkau lihat."

Sufyan Ats Tsauri berkata,'Hendaklah engkau merasa diawasi oleh Dzat yang mengetahui apa saja yang tersembunyi dari hal-hal yang tersembunyi. Hendaklah engkau berharap kepada Dzat yang memenuhi harapanmu. Dan hendaklah engkau takut kepada Dzat yang memiliki hukuman.” Abdullah bin Dinar berkata,"Pada suatu hari, aku pergi ke Makkah bersama Umar bin Khaththab. Di salah satu jalan, kami berhenti untuk istirahat, tiba-tiba seorang penggembala turun dari gunung. Umar bin Khaththab bertanya kepada penggembala tersebut. Hai penggembala, juallah seekor kambingmu kepada kami. Penggemala tersebut berkata,"Kambing-kambing ini bukan milikku, namun milik majikanku." Umar bin Khaththab berkata,'Katakan saja pada majikanmu, bahwa kambingnya dimakan serigala." Penggembala yang budak tersebut berkata," Kalau begitu di mana Allah 
?" Umar bin Khaththab menangis, kemudian pergi ke majikan penggembala tersebut, lalu membeli budak tersebut, dan memerdekakannya."

Dikisahkan bahwa seorang shalih berjalan melewati orang-orang yang sedang melempar, sedang salah seorang dari mereka duduk menyendiri. Orang shalih tersebut pergi kepada orang tersebut dan ingin mengajaknya berbicara, namun orang tersebut lebih dahulu berkata kepadanya,'Dzikir kepada Allah itu jauh lebih nikmat." Orang shalih bertanya kepada orang tersebut,"Engkau sendirian di sini ?" Orang tersebut menjawab,"Aku bersama Tuhanku, dan dua malaikat." Orang shalih bertanya kepada orang tersebut," Siapa yang mendahului orang-orang tersebut" ? Orang tersebut menjawab<"Yaitu orang-orang yang diampuni Allah." Orang shalih bertanya kepadanya,"Di manakah jalan itu ?" Orang tersebut memberi isyarat ke langit, kemudian dia berdiri dan pergi.

Muhasabah, adalah sikap batin yang berupaya senantiasa mengevaluasi diri terhadap apa yang telah dijalani dalam hidup ini, agar ke depan amal perbuatannya tidak menurun menjadi buruk. Merencanakan, memprogram, dan menjalani hidup dan kehidupan sesuai yang diperintahkan Allah ta'ala. Allah ta'ala memerintahkan orang yang beriman untuk muhasabah, perintah ini termaktub di dalam Al Qur-an surah Al Hasyr ayat 18, "Wahai orang yang beriman taqwalah kamu sekalian kepada Allah, dan hendaklah setiap diri memperhatikan apa yang diperbuatnya untuk hari esok (akhirat). Sesungguhnya Allah Maha Mengetahui apa yang kamu kerjakan.”

Umur manusia makin hari bertambah, sedang jatah umur yang diberikan oleh Allah ta'ala telah ditetapkan, artinya bertambahnya umur seseorang makin dekat dengan kematian. Dari sini sayangnya Allah ta'ala kepada manusia, maka selalu diingatkan agar manusia tidak terlena dengan kehidupan dunia, tetapi juga mempersiapkan kehidupannya di alam akhirat.

Di dalam bermuhasabah harus ada keberanian mengkritik diri sendiri, mu'aatabah 'alaa al nafs, semisal mengapa saya malas, mengapa tidak jujur, mengapa bermaksiat dan lain-lain, dan kritik atas diri sendiri itu harus ditindak lanjuti, diatasi supaya malas diganti dengan rajin, bohong diganti dengan jujur, maksiat diganti dengan taat. Agar seseorang bisa bermuhasabah maka harus 
memahami identitas diri, mengetahui jati diri, mengetahui kelemahan diri, memanfaatkan kelebihan diri, dan mensyukuri nikmat Allah ta'ala.

Aktifitas yang harus dimuhasabahi adalah ibadah, bukankah ibadah itu sebagai maksud diciptakannya manusia oleh Allah ta'ala? Apaka ibadah yang dilaksanakan sudah berdasarkan perintah dan aturan Allah ta'ala dan RasulNya? Bila seseorang tidak mengerti apa itu ibadah dan tidak peduli dengan ibadah, ini tanda orang yang paling celaka hidupnya. Rasulullah Muhammad SAW. menegaskan bahwa orang yang bijak adalah orang yang menyiapkan bekal untuk kehidupan abadi di akhirat.

Takut yang dimaksud adalah takut kepada Allah ta'ala, dan di dalam Al Quran memang ada ayat yang memerintahkan supaya manusia takut kepada Allah ta'ala. Takut bahwa Allah ta'ala ancamannya sangat dahsyat, yaitu neraka yang diperuntukkan bagi orang yang tidak beriman, buruk perbuatannya. Sebagaimana terjemah surah Ar Rahman ayat 46,'Dan bagi orang yang takut saat menghadap Rabbnya ada dua surga." Mujahid dan An Nakha'i berkata,'Yaitu seseorang yang ingat kepada Allah ketika hendak berbuat maksiat. Dia lalu meninggalkan perbuatan tersebut karena takut kepada Allah ta'ala." Muhammad bin Ali At Tirmidzi mengatakan,"Satu surga karena rasa takutnya kepada Rabbnya dan satu lagi karena dia meninggalkan dorongan syahwatnya."

Ibnu Abbas berkta,"Firman Allah, waliman khafa maqama rabbihi, dan bagi orang yang takut akan saat menghadap Rabbnya, yaitu ketika dia berada dihadapan Allah ta'ala pada hari kiamat, orang yang menahan dan tidak menuruti hawa nafsunya, tidak pula mengutamakan kehidupan dunia, dan yakin bahwa kehidupan akhirat lebih baik dan kekal. Karena itu dia melaksanakan perintah Allah ta'ala dan menjauhi laranganNya, maka dia akan mendapatkan dua surga. Dua surga yang dimaksud menurut satu riwayat dalam Hadits, surga yang peralatannya terdiri dari emas dan satunya lagi terdiri dari perak.

Imam Ghazali mengatakan bahwa buah dari takut kepada Allah ta'ala adalah sangat efektif mengekang nafsu syahwat syaithaniah, mengubah kemaksiatan yang dicintai menjadi dibenci. Rasa takut sesungguhnya mampu membakar syahwat, 
mendidik perilaku anggota badan, merendahkan dan melapangkan hati, menjauhkannya dari penyakit sombong, dendam dan dengki.

Lebih lanjut orang yang takut kepada Allah ta'ala itu bila amalnya tidak diterima oleh Allah ta'ala, sebab Allah ta'ala hanya menerima amal dari orang yang taqwa dan tentunya ikhlas. Takut bila amalnya ada unsur riya', yaitu menyandarkan amalnya bukan kepada Allah ta'ala, sebab Allah ta'ala hanya menerima ibadah yang murni tulus karena Allah ta'ala saja. Juga takut bila tidak mampu mempersembahkan dan memelihara kemurnian amal. Bagi yang beramal shalih sepuluh kali lipat pahalanya (Al A'am 160). Dan tentunya takut gagal dalam melaksanakan ketaatan, karena tidak ada taufiq melainkan pertolongan Allah ta'ala.

Abdullah bin Mubarak menggambarkan rasa takutnya dalam bait syair di bawah ini :

Hanya tepi-tepi punggung mereka yang menjadi kasur

Hanya lengan-lengan mereka yang menjadi bantal

Malam-malam mereka hanya berisi "KETAKUTAN"

Tidur mereka tak lain hanya desahan kekhawatiran

Tubuh mereka menguning seakan muka mereka menahan sakit

Menelan tumbuhan beracun

Tubuh-tubuh kurus yang tidak lagi menghiraukan lelah berjalan

Menuju Allah di tengah gulita, sementara manusia tidur

Terkadang mereka menangis, seakan pekikan mereka

Ketika menusia terlelap, rintih kerinduan akan tempat kembali

Majelis dzikir telah menjadi saksi

Dan mata berlinang karena takut kepada Allah azza wajalla

Sesungguhnya seseorang dapat mengetahui apakah dirinya termasuk orang yang takut kepada Allah ta'ala atau orang yang justru berani kepadaNya, yakni lalai sehingga bermaksiat kepadaNya. Berikut ini tanda-tanda orang yang takut kepada Allah ta'ala : Lisan suci dari hal yang buruk, perkataannya senantiasa baik, tidak menyakiti hati orang lain, tidak untuk mengumpat, tidak bergunjing, tidak untuk menfitnah dan lain-lain. Al Qur-an menegaskan, bahwa pendengaran, penglihatan, dan hati akan dimintai pertanggung jawaban dihadapan Allah ta'ala. Dalam hal 
menjaga lisan, Islam melarang ghibah, artinya bergunjing. Al Qur-an menegaskan,"...walaa yaghtab ba'dlukum ba'dlaa...;jangan bergunjing yang satu terhadap yang lain." Membicarakan keadaan seseorang dibelakangnya, artinya pembicaraannya tidak dihadapan obyek yang dibicarakan. Rasulullah saw. mengatakan,"Membicarakan keadaan seseorang yang menyebabkan dia benci atau marah bila didengarnya atau dikatakan dihadapannya." Tentu yang dibicarakan mengenai aib, kekurangan atau cacat seseorang. Tidak termasuk di dalamnya sifat pujian, sanjungan dan semisalnya.

Sebagai gambaran dari bergunjing peristiwa yang terjadi pada masa Rasulullah SAW., Aisyah, isteri Rasulullah SAW., dalam riwayat Ikrimah. Suatu hari Rasulullaah saw. menerima tamu yang pendek badannya, ini menarik perhatian Aisyah. Setelah tamu itu pergi, dari lisan Aisyah terucap kata-kata,"Tamunya tadi pendek. Mendengar ucapan Aisyah tadi, Rasulullah SAW. berkata kepadanya, "Engkau telah bergunjing. Engkau telah memuntahkan segumpal daging dari mulutmu."

"Bukankah benar apa yang telah saya katakan tadi," kata Aisyah. "Memang, benar...," sahut Rasulullah SAW. "Tetapi ucapanmu itu menyakitkan hatinya apabila didengarnya.". Pada kesempatan itu, Nabi menjelaskan lebih lengkap,"Yang dinamakan ghibah (gunjing) itu ialah engkau menyebutkan keadaan saudaramu yang tidak disenanginya. Adapun kalau memperkatakan keadaan yang sama sekali bertentangan dengan keadaan yang sebenarnya, maka itu adalah bohong."

Allah SWT. menegaskan pada ayat tersebut, bahwa menggunjingkan saudaranya itu tak ubahnya laksana makan daging saudaranya yang sudah mati. Tenntu setiap orang tidak akan makan daging saudaranya yag sudah mati. Dalam riwayat Hadist lain, dijelaskan Rasulullah sw., bahwa bergunjing itu sangat buruk, dan lebih buruk dari zina. Sebab orang yang berzina, kemudian bertaubat dengan sungguh-sungguh, maka dosanya insya Allah diampuni. Tetapi orang yang bergunjing, walau telah bertaubat kepada Allah ta'ala, tetapi masih memerlukan pemberian maaf dari orang yang digunjingkan.

Dan Islam memuji orang yang meninggalkan perkara yang tidak berguna, bahkan orang terbaik adalah yang banyak manfaatnya bagi kehidupan. 
Berusaha memelihara hati, supaya hatinya terhindar dari sifat buruk, tertata sedemikian rupa dengan hiasan indah Islam. Rasulullah SAW. menerangkan bahwa sumber baik, buruk seseorang terletak di hati, bila hatinya baik, maka baiklah orang tersebut. Tetapi bila hatinya buruk, maka buruk pulalah orang tersebut.

Fitrahnya hati itu baik, oleh karenanya tergantung apakah hati dibina dengan kebaikan dan keutamaan atau sebaliknya selalu disandingkan dengan sifat tercela dan hina. Pengaruh masing-masing sifat tersebut yang lebih dominan, maka sifat itulah yang akan menguasai hati, menjadikan seseorang bertindak terpuji atau hina. Berhati-hati dalam menjaga perut, tentu hubungannya dengan makanan dan minuman. Makanan dan minuman sebagai kebutuhan pokok manusia, dari sini siapapun tidak dapat melepaskan diri dari makan dan minum. Tetapi di dalam Islam ada makanan dan minuman yang karena zatnya ditetapkan keharamannya, maka menjadi haram atau dilarang untuk mengkonsumsinya. Semisal yang dilarang untuk di makan adalah daging babi, darah, bangkai, dan hewan yang disembelih bukan karena Allah ta'ala. Sedang minuman yang memabukkan diharamkan untuk diminum. Belum lagi makanan dan minuman yang zatnya halal, tetapi cara mendapatkannya dengan cara haram atau dilarang. Semisal mendapatkannya dengan cara mencuri, korupsi, juga mencampur yang halal dengan yang haram.

Beberapa terjemah sabda Rasulullah SAW. tentang yang haram:

Rasulullah SAW. bersabda,'Sesungguhnya Allah ta'ala memiliki malaikat yang bertugas di Baitul Maqdis, mereka senantiasa berdoa kepada Allah ta'ala,'Barangsiapa makan makanan yang haram, semoga amalnya tidak diterima, baik yang wajib maupun yang sunnah." Riwayat lain menyebutkan, siapa membeli pakaian dengan uang sebagian kecilnya ada yang haram, cara mendapatkannya, Allah swt. tidak menerima shalatnya selama ia masih menggunakan pakaian tersebut. Demikian halnya daging yang tumbuh dari yang haram, yang lebih berhak atas daging tersebut adalah neraka. Ibadah terdiri atas sepuluh bagian, yang sembilan erat kaitannya dengan rizki yang halal.

Abu Bakar Ash Shidiq ra. pernah diberi minum segelas susu oleh pembantunya, setelah minum susu tersebut, Abu Bakar bertanya tentang asal-usul susu tersebut. Jawab pembantunya,"Aku meramal untuk suatu kaum, lalu mereka 
memberiku upah dengan susu itu." Seketika itu Abu Bakar memasukkan jarinya ke dalam mulutnya, untuk memuntahkan susu yang telah diminumnya. Setelah itu Abu Bakar bedo'a,"Ya Allah, aku memohon ampunanMu atas sisa minuman yang ada di dalam aliran darahku.".

Terpeliharanya perut dari yang dilarang, memudahkan seseorang untuk berbuat taat kepada Allah ta'ala. Bila perut tidak dipelihara dari yang haram, terhalanglah seseorang untuk berbuat taat, yang muncul perbuatan maksiat. Di sini memelihara itu sendiri ketaatan, maka akan muncul sikap taat, bila yang ada kekufuran menolak adanya aturan Allah ta'ala, maka yang dihasilkan adalah maksiat. Memelihara pandangan mata merupakan perintah Allah swt. dalam Al Quran dan Hadits. Ada memandang yang diharamkan dan ada memandang diperbolehkan oleh Islam. Setiap yang dilarang bila bisa dicegah akan mendatangkan manfaat, bila larangan itu dilanggar akan mendatangkan madharat atau kerusakan. Al Qur-an suci menyabdakan dalam pengertian laki-laki dan perempuan beriman supaya menjaga pandangannya, yang demikian itu menempatkan pada kedudukan yang terhormat disisi Allah ta'ala.

Hadits memberitakan, tentang sahabat yang menyatakan memandang dengan tiba-tiba artinya tidak disengaja tentunya terhadap lawan jenisnya yang memungkinkan menimbulkan keinginan untuk memandang lagi, maka Rasulullah saw. menyuruh memalingkan pandangan. Sedang pandangan yang ada keinginan nafsu memandang sebagai anak panah dari Iblis, siapa yang menghindarkannya kerana takut kepada Allah ta'ala dikaruniai Allah ta'ala keimanan ynag terasa manis di hati. Memelihara pandangan itu faedahnya adalah menunaikan titah Allah ta'ala, dan itu hanya bisa dilaksanakan oleh orang yang beriman dan gemar beramal shalih. Melaksanakan titah Allah ta'ala mendatangkan kebahagiaan dunia dan akhirat, sedangkan mengumbar pandangan menimbulkan hati gelisah. Melepaskan hati dari tawanan syahwat, sebab orang yang tertawan oleh pandangan matanya itulah sebenarnya orang yang tertawan. Orang yang bisa memelihara pandangan berarti telah terbentengi dirinya dari bujukan syaithan dan menundukkan pandangan berarti telah mengkosongkan hati dari berbagai kemaksiatan. 
Memelihara kaki dan tangan agar tidak terperosok ke dalam yang haram. Tangan dan kaki adalah anggota tubuh yang paling banyak digunakan untuk beraktifitas, maka penjagaan agar ke dua anggota tubuh tersebut tetap pada keridlaan Allah ta'ala merupakan keharusan. Melakukan maksiat pasti dengan kaki dan tangan, anggota badan tersebut bukan buatannya sendiri, tetapi tinggal menggunakan, yang berarti itu ciptaan dan pemberian Pencipta, Allah ta'ala.

Pada hari hisab, Yaumul Hisab, lisan manusia ditutup tidak dapat berbicara, kecuali diijinkan Allah ta'ala, justeru ke dua tangannya berbicara atas apa yang telah dikerjakan selama hidup di dunia, sedang kakinya menjadi saksi atas apa yang telah dikatakan oleh tangannya. Seakan kalimat tersebut ngoyoworo atau tidak mungkin, tetapi bukankah tangan ini saat di dunia inipun sudah bisa berbicara ? Bagaiamana cara bicaranya tangan tersebut?

Setiap orang dengan tangannya mempunyai sidik jari, dan tidak ada sidik jari yang sama orang yang satu dengan lainnya walau tentu jumlah manusia milyar, ini wujud ke Maha Agungan Allah ta'ala. Dari sidik jari itulah dikembangkan ilmu di Kepolisian untuk mengungkap berbagai kasus kejahatan. Sidik jari telah berkata bahwa pemiliknya telah melakukan kejahatan. Surah Yasin ayat 65 menegaskan, terjemahnya ,"Pada hari ini Kami tutup mulut mereka dan berbicaralah tangan mereka dan kaki mereka menjadi saksi atas apa yang telah mereka kerjakan.”

Berhati-hati dalam setiap ketaatannya kepada Allah ta'ala, sebab ketaatan bisa menjadi rusak bila pemiliknya tidak memiliki pengetahuan bagaimana memelihara, menstabilkan, atau meningkatkannya. Ketaatan kepada Allah ta'ala bukan semata hasil karya seseorang, lebih dari itu adalah karunia pemberianNya. Ketaatan diyakini sebagai karunia Allah ta'ala menghasilkan sikap tawadlu' dan menepis sifat takabur. Bila ketaatan dibanggakan dan ditakaburkan maka hilanglah nilai-nilai ketaatan dihadirat Allah ta'ala. Kalimat yang tepat bagi seorang Muslim atas apa yang melekat pada dirinya adalah Allah ta'ala yang mengaruniakan kepadaku. Demikian itu sikap tawadlu' hamba kepada Rabbnya. Bukannya saya bisa, artinya dengan mendahulukan kata saya, hakekatnya menafikan kudrah dan iradah Allah ta'ala pada makhlukNya, dan itu menumbuhkan sikap takabur. 


\section{Kesimpulan}

Akhlaq ajaran yang sempurna karena turun dari Allah ta'ala secara wahyu, dan Dia Maha Mengetahui tentang ciptaanNya yaitu manusia, wahyu itu untuk mendidik dan membina menuju karakter manusia yang sempurna dan mulya. Ini difahami akhlaq bagian dari ajaran pokok dalam Islam dan tidak dapat dipisahkaan dengan aspek pokok ajaran yang mendahuluinya, yaitu aqidah dan syari'ah.

Akhlaqul karimah yang mewujud pada pribadi seseorang mengantarkan pada kedudukan yang mulya di dunia dan di akhirat, sedang kehidupan akhirat lebih baik dan kekal. Akhlaq tidak dapat dipisahkan dengan ketaatan kepada Allah ta'ala, semakin taat seorang hamba kepada Allah ta'ala, akhlaqnya semakin bertambah baik atau mulya, dan memang ketaatan itu harus menghasilkan tingkah laku luhur.

Akhlaq dalam Islam harus didakwahkan untuk menepis pihak yang selalu menyuarakan kegarangan Islam dalam menjalankan dakwahnya, yang sebenarnya Islam itu misinya rahmatan lil alamin. Menyakiti hati sesama manusia itupun tidak diajarkan di dalam akhlaq Islam, menggembirakan orang lain dalam tataran ridla Allah ta'ala itu prinsip utama akhlaq Islam.

\section{Daftar Pustaka}

Abu Bakar Jabir al Jazairi, 2005,"Ensiklopedi Islam,” Penerjemah Fadli Bahri Lc., Darul Falah, Jakarta

Departemen Agama RI.,1989,"Al Qur-an dan Terjemahnya," Mahkota, Surabaya

Imam Ghazali, 2008,"Ringkasan Ihya Ulumuddin,"Penerjemah Abdul Rasyad Siddiq, Akbar, Jakarta

Majdi Fathi as Sayyid, 2009,"Menghadirkan Rasa Takut kepada Allah,"Penerjemah Hikmatullah, Aqwam, Solo

Shafiyurrahman al Mubarakfury, 2010,"Sirah Nabawiyah,"Penerjemah Sulaiman Abdurrahim, Sygma Publishing, Bandung

Zulkabir dkk.,1993,’'Islam Konseptual dan Kontekstual, Itqan, Bandung

Zakaria Ghulam Qadir al Bakistani, 2009,"Ensiklopedi Islam,’Penerjemah Izzudin Karimi, Pustaka Yassir, Surabaya 